\title{
Foreign ownership and its effects on employment and wages: the case of Sweden
}

\author{
Runar Brännlund', Jonas Nordström ${ }^{2}$, Jesper Stage ${ }^{3 *}$ and Dick Svedin ${ }^{4}$
}

\author{
* Correspondence: \\ jesper.stage@ltu.se \\ ${ }^{3}$ Department of Business \\ Administration, Technology and \\ Social Sciences, Luleå University of \\ Technology, SE 97187 Luleå, \\ Sweden \\ Full list of author information is \\ available at the end of the article
}

\begin{abstract}
In this paper, we study how foreign ownership of Swedish companies affects employment and wages. To study these effects, we specify a model based on the assumption that the Swedish labour market can be described as one where trade unions and employers bargain over employment and wages. Our hypothesis is that bargaining power is affected by institutional settings and the ownership of the firm. To test our hypothesis, we used a panel data set of 242 large Swedish manufacturing firms over the period 1980-2005. The results indicate no significant impact of foreign ownership on employment or wages in Sweden.

Jel codes: J30, J50, D21, C33

Keywords: Bargaining power, Trade union, Employment, Wages
\end{abstract}

\section{Introduction}

The purpose of this paper is to examine how foreign ownership of companies acting in Sweden has affected the employment and wage setup. Although Sweden has a tradition of labour market agreements such as collective bargaining between unions and employers, the assumption in the present paper is that foreign-owned firms are not as committed to this "social contract" as domestically owned firms are, which makes the threat of foreign-owned business activities moving out of Sweden credible. This line of reasoning reflects public debate on this issue. According to our hypothesis, then, foreign ownership will exert a downward pressure on wages in a unionised labour market. Sweden, with its traditionally strong unions, provides an interesting case study for this hypothesis.

Due to globalisation as well as the deregulation of capital markets, capital movements have increased steadily in recent years. As a result, the number of people employed in foreign-owned firms has also increased rapidly: in Sweden, for example, the share of individuals employed in firms controlled by foreign owners (defined in this paper as a firm where a foreign owner holds more than half of the voting rights of the enterprise in question, either directly or through a parent company) more than quadrupled between 1980 and 2005 (see Fig. 1). At the end of 2005, over $20 \%$ of all employees in Sweden were working for foreign-owned firms; for the manufacturing sector studied here, the share was substantially higher.

(c) 2016 Brännlund et al. Open Access This article is distributed under the terms of the Creative Commons Attribution 4.0 International License (http://creativecommons.org/licenses/by/4.0/), which permits unrestricted use, distribution, and reproduction in any medium, provided you give appropriate credit to the original author(s) and the source, provide a link to the Creative Commons license, and indicate if changes were made. 


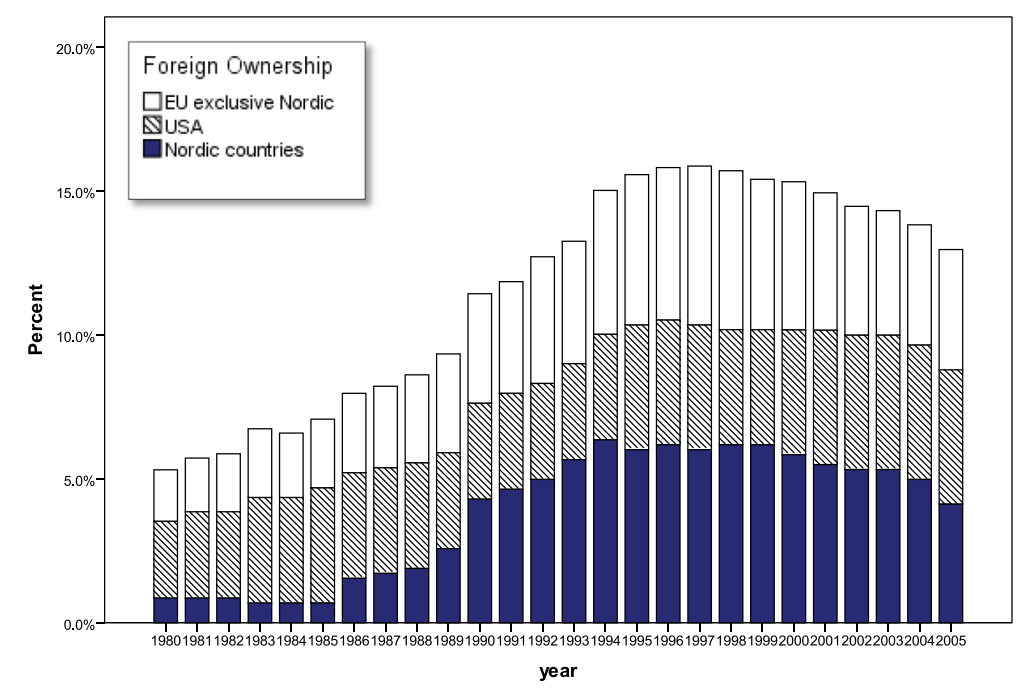

Fig. 1 Share and number of foreign companies in Sweden and their share of employed individuals, 1980-2010. Source: Swedish Agency for Growth Policy Analysis

Such an increase of foreign control may well have affected labour market conditions. In a number of countries, fear that foreign ownership could lead to worsened labour market conditions has been an important component of the domestic policy debate, and this concern has been reflected in the literature as well. Authors such as Bughin and Vannini (1995) and Radulescu and Robson (2008), for example, take it as given that foreign-owned firms have the option of ignoring local unions. Cowling and Sugden (1987), Huizinga (1990), and Ramsay (1995), similarly, take for granted that increased importance of international investment flows will reduce the bargaining power of national unions. The implicit hypothesis is that a switch from domestic to foreign ownership has a detrimental effect on a trade union's bargaining power, as foreign owners can make more credible threats than domestic owners of moving the activity abroad, and that this may then affect both employment and wages.

To accomplish our objectives, we will specify a model that is essentially based on the assumption that the Swedish labour market can be described as one where trade unions and employers bargain over both employment and wages (Alogoskoufis and Manning 1991). The intuition is that bargaining power, which affects both equilibrium wage and equilibrium employment levels, may be modelled as a function of various industry and labour market characteristics, including type of ownership. To test our hypothesis, we used a panel data set of 242 firms operating during the period 1980-2005.

One reason that we chose to conduct the analysis with a bargaining model of this kind is that Sweden has a long history of high trade union density among workers in manufacturing industries; apart from a few years in the 1980s when Denmark's trade union density was slightly higher, Sweden's trade union density has been the highest among the industrialised countries throughout the period studied in this paper. This also means that to the extent that unions' bargaining power is affected by increased foreign ownership, this effect should be more pronounced in Sweden-where unions' bargaining power was clearly very high to begin with-than in countries where unions were never particularly strong in the first place. 
The rest of the paper is organised as follows: Section 2 presents previous literature in the field, while Section 3 outlines the theoretical model underlying our empirical model. Here, we do not explicitly take foreign ownership into consideration but instead focus on how employment and wages may be determined in a unionised economy and how the respective bargaining power of the union and the employer may affect wage and employment outcomes. In Section 4, we present the data used in the empirical analysis. Section 5 sets up our econometric model, which takes foreign ownership into account. The results from the econometric model are presented in Section 6, after which Section 7 offers some concluding comments.

\section{Previous literature}

In a recent study, Dumont et al. (2012) show that the bargaining position of low-skilled labour appears to fall with increases in imports and offshoring, while the bargaining power of high-skilled workers is affected positively by research and development activities. They found that trade unions seemed to focus on wages rather than employment. Moreover, Modén (1998) revealed that foreign ownership led to an increase in labour productivity in Swedish manufacturing, implying a reduction in employment (at least in the short run); however, Bandick and Karpaty (2011) found no negative impact of foreign ownership on employment. Navaretti et al. (2003) found that, for any given wage increase, multinational firms reduced total employment less than national firms did. These authors (ibid.) also established that labour market regulations were largely irrelevant to the labour market behaviour exhibited by multinational firms and concluded that concerns about labour market regulation scaring off foreign direct investment (FDI) seemed unfounded.

There are by now several theoretical studies trying to explain the effect of the flow of FDI on wages and employment. Most of these studies employ a Nash bargaining approach to model the strategic bargaining relationship between a union and a firm. Bughin and Vannini (1995), using such a model, established that trade unions were indifferent when it came to choosing between exporting or investing abroad. Naylor and Santoni (2003) argued that FDI in a potential host country was more likely if the union wage-bargaining power in that country was weaker and if there was a lower degree of substitutability between potential rivals' products. Zhao (1995) and Zhao (1998) found that, with symmetric FDI flows in both directions, the negotiated wage decreased for every level of employment, while each firm's profit increased; such FDI flows increased employment and national welfare if the union was wage-oriented but decreased employment and national welfare if the union was employment-oriented.

A number of empirical studies have examined the effects of foreign ownership on wages. A frequent finding is that foreign-owned firms are more productive than domestically owned firms, although this finding tends to be sensitive to the exact specification used. This higher productivity in turn tends to translate into higher wages, although this effect frequently increases the equilibrium wage in the entire sector and thus spills over into domestically owned firms in the same sector as well (see e.g. Lipsey 1994; Feliciano and Lipsey 1999). Concerning ownership per se, Hatzius (2000) presented evidence to the effect that the bargaining power of employees was reduced when domestic (British) firms were acquired by foreign owners. Aitken et al. (1996) investigated the wages paid by domestic and foreign-owned firms in Mexico, the USA, and Venezuela. 
They presented evidence that foreign investment in a sector led to higher productivity and higher wages, but that (at least for the USA) wages also increased in domestically owned firms in the same sector. Girma et al. (2001) found, for the UK, that a large share of the difference in productivity was linked to larger size and larger capital intensity of foreign-owned firms. They found little indication of wage spillovers from foreign-owned firms to domestically owned firms, although they noted that the econometric specification that they used may have masked some of the spillover effects. Conyon et al. (2002), using a short panel of UK firms that were acquired either by foreign or by new domestic owners, found that wages increased by $3.4 \%$ when foreign investors acquired the companies compared to when the companies were acquired by new domestic owners; they attributed the entire wage difference to productivity differences. Griffith and Simpson (2003) also established a positive premium for foreign-owned companies in the UK but attributed the entire wage and productivity difference to differences in investment levels. For Portugal, Almeida (2007) presented evidence that the workforce in foreign-owned companies was more highly skilled and was paid a higher wage premium than in domestically owned companies but also found that these differences were entirely attributable to cherry picking of acquisition objects by foreign investors. Also studying Portugal, Martins (2004) revealed a positive average-wage premium for the years 1991-1999 but found successively smaller premia when controls were added for firm type and worker type. Using Finnish data, Huttunen (2007) established that, when Finnish companies passed into foreign ownership, the wage dispersion within the companies increased. However, in a related study of Brazil, Martins and Esteves (2008) found no evidence that foreign acquisitions resulted in higher wage premiums; instead, such takeovers tended to decrease the demand for labour.

To sum up, one could say that, in general, foreign ownership tends to increase the wage rate, largely because of improved labour productivity, and that at least some studies have found that these wage increases spill over into other firms in the same sector. Nonetheless, it needs to be borne in mind that most of the previous studies have looked at labour markets considerably less unionised than Sweden's. It also needs to be borne in mind that the type of firm acquired by foreign investors may be different from an average firm, in the country and even in the same sector.

\section{The model}

We use a bargaining model first developed by Manning (1987). We derive the structural equations for determining employment and wages on the assumption that both are sequentially negotiated between an employer and a trade union and that these parties are completely informed. The resulting model will be used as the basis for an empirical analysis in Section 4. The basic idea here is that the employer seeks to maximise profit, given a production technology, and that the union seeks to maximise its members' utility. How well each party succeeds depends on its bargaining strength. Bargaining strength may, in turn, depend on a number of different things, one of which is the institutional setting. In this paper, we ultimately set out to test whether foreign ownership affects employment and wage-setting, and our hypothesis is that if there is an effect, this effect may be transferred through the trade union's bargaining power.

In most collective bargaining, there is a two-stage negotiation process where wages are determined prior to employment. In Sweden, such employment contracts often last 
for a year or two. Partly because of this, trade unions may act differently-and may have a different bargaining power-when negotiating about wages, compared to when they are negotiating about employment. Manning (1987) offers a theoretical explanation for this phenomenon. Firstly, owing to uncertainty and the impossibility of concluding complete contracts that will cover all the possible scenarios and supplements, it may be best to reach agreement on wages first and then determine employment. Secondly, wage negotiations are mostly carried out at a higher level, e.g. nationally, while employment levels are usually negotiated at plant level.

To start, we assume that supply of labour is given by a set of workers, where each worker has a unit of labour that they supply with no disutility. Furthermore, the members of the trade union are assumed to have identical preferences that are represented by the following (indirect) utility function:

$$
U=P u(w)+(1-P) u(R)
$$

where $w$ denotes the real wage, $P$ is the probability of being employed in the firm and $R$ denotes the expected real income of a worker who loses his/her job in the firm (the reservation wage). $u(\cdot)$ is strictly increasing and concave. If we normalise the labour force to unity, the union utility function (1) can be written as

$$
U(w, L, R)=L u(w)+(1-L) u(R)
$$

where $L$ is the share of the labour force that is employed and $(1-L)$ the unemployed share.

The profit-maximising firm is assumed to use labour, $L$, and capital, $K$, and a strictly concave technology, $f$, to produce its output. Assuming that capital is fixed in the short run, the firm's short-run profit can be written as

$$
\Pi(L, K, p, w)=p f(L, K)-w L
$$

where $p$ is the price of output.

The first stage in the negotiation process between firm and trade union is where the parties bargain over the wage. In the second stage, the parties bargain over the employment level-subject to the negotiated wage from the first stage. The negotiation process between the union and employer is formalised by the strategic model of bargaining between completely informed players. This can be set up as a Nash product, where the objective is to maximise a weighted product of the union's utility and the firm's profit. The weights are determined by the bargaining power, which in turn is a function of a vector of variables, $\mathbf{z}$, such as institutional setting, firm characteristics, labour market conditions and type of ownership. The problem can be solved backwards, i.e. by solving for the employment conditional on a given wage, as follows:

$$
\max _{L}\left(U(w, L, R)-U_{0}\right)^{\Phi_{2}(\mathbf{z})}\left(\Pi(L, K, p, w)-\Pi_{0}\right)^{1-\Phi_{2}(\mathbf{z})}
$$

where $\Phi_{2} \in[0,1]$ is the union's bargaining power over employment. If $\Phi_{2}=0$, the firm sets the employment level. $U_{0}$ and $\Pi_{0}$ are the fallback utility and fallback profit, assumed to be given by $U_{0}=u(R)$ and $\Pi_{0}=0$, respectively.

The first-order condition to this problem can be written as, 


$$
\Phi_{2}(\mathbf{z}) \frac{p f(L, K)}{L}+\left(1-\Phi_{2}(\mathbf{z})\right) p f_{L}(L, K)=w .
$$

From Eq. (5), we see that the employment level is chosen such that a linear combination of the value of the average productivity of labour and the value of the marginal productivity of labour is equal to the wage. If $\Phi_{2}=1$, the firm has no influence on determining employment, and the wage will be set equal to the value of the average product. If $\Phi_{2}=0$, then employment is chosen such that the marginal product of labour equals the wage.

Thus, Eq. (5) then gives us the employment level as a function of the given real wage, the producer price, the capital stock and the trade union's bargaining power:

$$
L=L\left(w, p, K, \Phi_{2}(\mathbf{z})\right)
$$

The first stage in the negotiation process is where the union and the employer negotiate over wages, given the employment level from the second stage, i.e.

$$
\max _{w}\left(U\left(w, R, L\left(w, p, K, \Phi_{2}(\mathbf{z})\right)\right)-U_{0}\right)^{\Phi_{1}(\mathbf{z})}\left(\Pi\left(L\left(w, p, K, \Phi_{2}(\mathbf{z})\right), K, w\right)-\Pi_{0}\right)^{1-\Phi_{1}(\mathbf{z})}
$$

where $\Phi_{1} \in[0,1]$ is the trade union's bargaining power in the wage-setting stage. If $\Phi_{1}=1$, the trade union sets the wage, which in combination with $\Phi_{2}=0$ gives us the monopoly model (see e.g. Dunlop 1944). ${ }^{1}$ If $\Phi_{1}$ and $\Phi_{2}$ are equal, we have the efficient bargaining model of McDonald and Solow (1981); Manning (1987) notes that in practice, $\Phi_{1}>\Phi_{2}$ in many real-world unionised labour markets and that different bargaining strengths on different issues are a key source of economic inefficiencies associated with unionisation.

The first-order condition to Eq. (7) then gives us the equilibrium wage-setting rule, which can be written as,

$$
w^{*}=w\left(L\left(w, p, K, \Phi_{2}(\mathbf{z})\right), R, \Phi_{1}(\mathbf{z})\right) .
$$

Equation (8) indicates that the wage-setting rule, in general, is a function of the employment level (and, thus, of bargaining power over employment), of the reservation wage and of bargaining power over the wage. ${ }^{2}$ Substituting Eq. (8) into (6) then gives us the equilibrium level of employment, i.e.

$$
L^{*}=L\left(w^{*}, p, K, \Phi_{2}(\mathbf{z})\right)=L\left(p, K, R, \Phi_{2}(\mathbf{z}), \Phi_{1}(\mathbf{z})\right) .
$$

Following Manning (1987), by assuming that $u(w)=w, u(R)=R$ and $U_{0}=R$, it can be shown that

$$
\frac{\partial L^{*}}{\partial \Phi_{1}} \leq 0, \frac{\partial L^{*}}{\partial \Phi_{2}} \geq 0, \frac{\partial w^{*}}{\partial \Phi_{1}} \geq 0, \frac{\partial w^{*}}{\partial \Phi_{2}} ? 0
$$

Perhaps surprisingly, we cannot say how the wage is affected by a change in bargaining power over employment without having a more explicit model specification that lets us determine the wage-setting rule (e.g. if the production function is of a Cobb-Douglas type, it can be shown that $\left.\partial w / \partial \Phi_{2}=0\right)$.

Equations (8) and (9) constitute a system of equations describing equilibrium employment and equilibrium wage determination that can, in principle, be estimated. A problem, however, is that the bargaining parameters, $\Phi_{1}$ and $\Phi_{2}$, are not directly 
observable. To get around this problem, we will follow the empirical approach developed by Alogoskoufis and Manning (1991), Doiron (1992) and Vannetelbosch (1996), in which it is assumed that bargaining power can be expressed as a function of a vector of exogenous variables, $\mathbf{z}$.

In particular, we are interested in investigating how differences in ownership affect bargaining power and, ultimately, employment and wage-setting. If the belief that foreign ownership reduces unions' bargaining power is correct, we would expect the bargaining parameters to be lower for foreign-owned firms. However, even if there is an impact on unions' bargaining power, it is not clear which of the two bargaining parameters will be affected the most. Thus, the actual impact of foreign ownership on the two bargaining parameters is a matter for empirical analysis.

\section{Data}

The data we used was a panel data set for manufacturing firms in Sweden compiled by one of the authors. The panel covers the years 1980 to 2005 and consists of all Swedish manufacturing firms with at least 50 employees. A classification of the industries in question is given in Table 3 in the Appendix. Since the classification of industries changed during the period studied, only firms that belonged to the same industry in both classification systems (SNI69 and SNI92) were included, and in order to permit analysis of effects over time, only firms with at least five consecutive observations were retained in the dataset. In Sweden, 242 firms met all these requirements and were thus included in the dataset. To be classified as foreign-owned, more than $50 \%$ of the votes in the company had to be held by foreigners.

The variables used in the study are presented in Table 4 of the Appendix, with their definitions. The data for wages, employment and capital for each firm were collected from each respective firm's annual report, which by law have to be submitted to the Swedish Companies Registration Office. The number of employees in the data set covers both white- and blue-collar workers, while the trade union data (discussed below) cover blue-collar workers (see e.g. Huttunen 2007). This could give us a bias in the measure of wages, since salaries for white-collar workers are significantly higher than those for their blue-collar counterparts (see e.g. Huttunen 2007). However, in our case, this is a minor problem since all the firms in the data set are quite large plants and blue-collar workers dominate their labour forces. The variables that are assumed to affect the bargaining power through the $\Phi_{1}$ and $\Phi_{2}$ functions are, in addition to country-specific ownership, trade union density in the industry and openness; these reveal how open the respective industries are to international trade. To calculate the measure of openness for each industry, defined as (export + import)/total sales (see e.g. Leamer 1987), data on exports, imports and total sales in each industry were collected from Statistics Sweden's industry statistics. The average unemployment level for each trade union's membership was obtained from Swedish Public Employment Service statistics. Data on union density were collected from the respective trade union's annual reports, and the matching between trade unions and companies was based on trade union representation in companies, as reported in such unions' annual reports.

From Fig. 2, we can see that the share of foreign-owned firms in the sample increased sharply-from a level of about $5 \%$ in 1980 to approximately $13 \%$ in 2005. It is also 


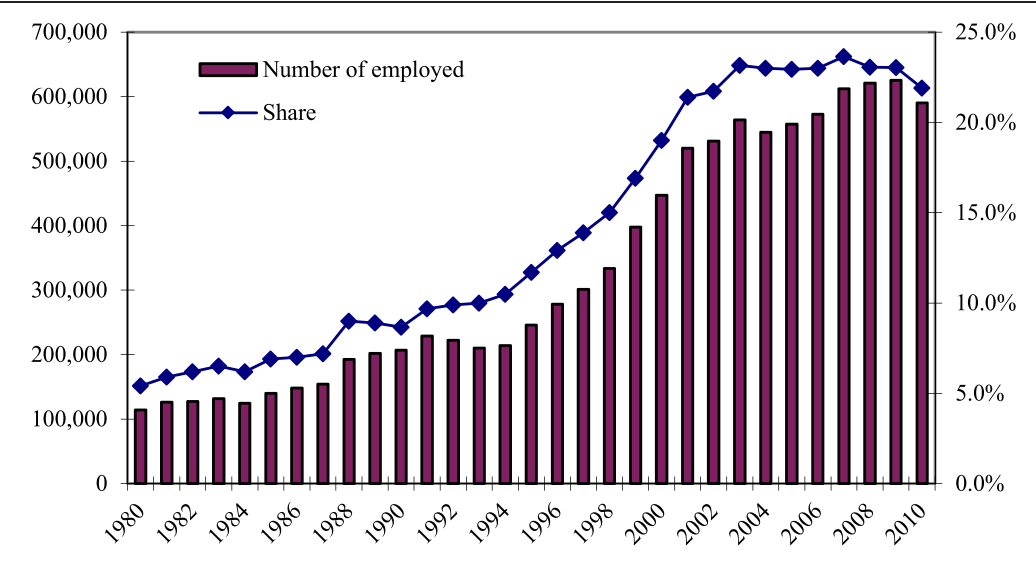

Fig. 2 Foreign ownership, 1980-2005 (\%)

clear from Fig. 1 that most foreign owners of the sample companies originated from European countries.

\section{Econometric specification}

To test our hypothesis concerning differences in bargaining power between trade unions and firms with different owners, we estimated the derived wage and employment equations simultaneously. Equations (6) and (8) in Section 2 gave us the following system:

$$
\begin{gathered}
w=w\left(L, R, \Phi_{1}\left(\mathbf{z}_{1}\right)\right) \\
L=L\left(w, p, K, \Phi_{2}\left(\mathbf{z}_{2}\right)\right) .
\end{gathered}
$$

In addition to the country-specific ownership of the firm, the bargaining power $\Phi_{1}\left(\mathbf{z}_{1}\right)$ in the wage equation is assumed to be a function of the industries' union density, the industries' openness to international trade and the fraction of trade unionists living on unemployment benefits. The bargaining power $\Phi_{2}\left(\mathbf{z}_{2}\right)$ in the employment equation includes the same set of variables as $\Phi_{1}\left(\mathbf{z}_{1}\right)$, with the exception of the fraction of trade unionists living on unemployment benefits. We have chosen to exclude this variable due to the short-run dependence between the number of workers in a firm and unemployment in the industry.

The lowest mean wage per employee is consistently found among workers in the pulp, paper and paperboard industry. The reservation wage at time $t$ has, therefore, been specified as the lowest observed wage per employee among these workers at time $t$.

In specifying the simultaneous equation system, we consider a non-linear specification of the $\Phi$ functions. This is to ensure that the bargaining power lies between 0 and 1 and to facilitate the analysis of the trade union's bargaining power. The system is specified as a one-way error component model, as follows:

$$
\begin{aligned}
& w_{i t}=L_{i t} \beta_{1}+x_{1 i t} \gamma_{1}+\Phi_{1 t}\left(\mathbf{z}_{1 i t}, \boldsymbol{\rho}_{1}\right)+\mu_{1 i}+v_{1 i t}, \quad i=1, \ldots, N \\
& L_{i t}=w_{i t} \beta_{2}+\mathbf{x}_{2 i t} \boldsymbol{\gamma}_{2}+\Phi_{2 t}\left(\mathbf{z}_{2 i t}, \boldsymbol{\rho}_{2}\right)+\mu_{2 i}+v_{2 i t}, \quad t=1, \ldots, T
\end{aligned}
$$

where $\mu_{i}$ is an unobservable individual-specific effect, $v_{i t}$ is the remainder disturbance in respective equation, $x_{1 i t}=R_{i t}, \mathbf{x}_{2 i t}=\left[p_{i t}, K_{i t}\right]$ and $\gamma_{2}^{\prime}=\left[\gamma_{p}^{\prime}, \gamma_{K}^{\prime}\right]$. The $\Phi$ functions are 
specified as logistic distribution functions, $\Phi_{1}\left(\mathbf{z}_{1}\right)=1 /\left[1+\exp \left(-\mathbf{z}_{1} \boldsymbol{\rho}_{1}\right)\right]$ and $\Phi_{2}\left(\mathbf{z}_{2}\right)=1 /[1+$ $\left.\exp \left(-\mathbf{z}_{2} \boldsymbol{\rho}_{2}\right)\right]$, so that $\Phi_{1} \in[0,1]$ and $\Phi_{2} \in[0,1]$.

Before estimation, the original data are transformed into deviations from their time mean, such that the typical element of the wage series, for example, becomes $w_{i t}^{\circ}=w_{i t}-\bar{w}_{i}$, with $\bar{w}_{i}=T^{-1} \sum_{s=1}^{T} w_{i s}$. Although this within-group transformation eliminates timeinvariant regressors, a constant is still needed in each equation since $E\left[\Phi_{k}\left(\mathbf{z}_{k}\right)\right] \neq 0$. All variables, except the ones included in $\mathbf{z}_{k}[k=1,2]$, were log-transformed (this is in line with previous empirical studies, see e.g. Alogoskoufis and Manning (1991) or Vannetelbosch (1996)). To both equations, we also added a linear time trend.

The within-group estimation of the non-linear simultaneous equation systems was carried out by the generalised method of moments (GMM), using $Z^{\circ}=\left[x_{1}^{\circ}, \mathbf{x}_{2}^{\circ}, \mathbf{z}\right]$ as instruments. ${ }^{3}$ The variables that are used as instruments are the output price (producer price index), trade union density, openness, unemployment level, time and each dummy for owner's domicile. A general description of simultaneous equation estimation is given in Hausman (1983), for example, while a description of non-linear GMM estimation of simultaneous equations based on panel data can be found in Arellano (2003), among others. To account for heteroscedasticity and autocorrelation, we use a Newey and West estimator of the covariance matrix. The covariance matrix was adjusted to account for the non-estimated fixed effects.

\section{Results}

The estimation results are presented in Tables 1 and 2. Two sets of models are estimated: one where all foreign-owned firms are examined jointly and one where they are separated by the owners' domicile. The $F$ test indicates that we cannot reject the hypothesis that all foreign firms can be examined jointly. In the calculations of the Newey and West covariance matrix, autocovariances of lag 1 are used since the test statistics show the error terms in both equations follow an AR1 process.

If we study the wage equation first, we can see from Table 1 that a higher reservation wage will increase wages, as expected; a $1 \%$ increase in the reservation wage increases the actual wage by a quarter of a per cent. We can also see that the number of employees in a firm has a significantly positive effect on wages, which indicates that, on average, larger companies pay higher wages to their employees, although this effect is weaker than that of the reservation wage. Not surprisingly, higher unemployment in a sector reduces the bargaining power of the union in that sector.

The effects of foreign ownership on bargaining power over the wage negotiation are unclear, however: half of the dummies for owner's domicile have positive and half have negative effects on wages, but few are statistically significant. The only exceptions are Denmark, which is positively significant, and Norway and Finland, which are both significantly negative; the dummies for all other countries are insignificant. In the partial model, where all foreign-owned firms are studied jointly, the dummy for foreign ownership is not statistically significant. Thus, there is no clear evidence that foreign ownership affects unions' bargaining power over wages.

Turning to the employment equation (Table 2), we can observe that an increase in the wage rate has a negatively significant effect on employment, while a larger capital 
Table 1 Estimation results for the wage equation (GMM estimation)

\begin{tabular}{|c|c|c|c|c|}
\hline & \multicolumn{2}{|l|}{ Partial model } & \multicolumn{2}{|l|}{ Full model } \\
\hline & Estimate & Standard error & Estimate & Standard error \\
\hline Reservation wage & $0.2544^{* * *}$ & 0.0146 & $0.2457^{* * *}$ & 0.0144 \\
\hline Employment & $0.1273^{* * *}$ & 0.0336 & $0.1251^{* * *}$ & 0.0329 \\
\hline Openness & -0.0275 & 0.0385 & -0.0267 & 0.0356 \\
\hline Union density & 0.4830 & 0.3909 & 0.3255 & 0.2854 \\
\hline Unemployment level & $-3.39 \times 10^{-5^{* * *}}$ & $2.84 \times 10^{-6}$ & $-2.59 \times 10^{-5^{* * *}}$ & $9.97 \times 10^{-6}$ \\
\hline Foreign ownership & 0.1484 & 0.1879 & - & - \\
\hline Austria and Switzerland & - & - & -0.0661 & 0.0803 \\
\hline Belgium and Netherlands & - & - & 0.0760 & 0.0800 \\
\hline Denmark & - & - & $0.3669^{* * *}$ & 0.1247 \\
\hline UK and Ireland & - & - & -0.0001 & 0.0779 \\
\hline Finland & - & - & $-0.2341^{* * *}$ & 0.0723 \\
\hline France & - & - & -0.0256 & 0.0741 \\
\hline Germany & - & - & 0.1004 & 0.0826 \\
\hline Italy & - & - & 0.1438 & 0.1420 \\
\hline Norway & - & - & $-0.3835^{* * *}$ & 0.1136 \\
\hline US and Canada & - & - & 0.0253 & 0.0697 \\
\hline Time & $0.0391^{* * *}$ & 0.0014 & $0.0417^{* * *}$ & 0.0014 \\
\hline Constant & $-78.5236^{* * *}$ & 2.7232 & $-1.1153^{* * *}$ & 0.0622 \\
\hline Mean $\Phi_{1}$ & $0.6641^{* * *}$ & $0.1095^{a}$ & 0.566 & $0.0588^{a}$ \\
\hline$R$-squared & 0.6839 & & 0.6879 & \\
\hline Durbin-Watson & 1.1215 & & 1.1134 & \\
\hline$F$ test & 5.5905 & & & \\
\hline
\end{tabular}

***0.1\% level

${ }^{\text {a }}$ The Delta method was used to calculate the standard errors

stock increases employment. A higher producer price will also have a significant positive effect. These results are all in line with expectations. Increased openness has a negative impact on employment. As regards the effect on bargaining power, we can see that only a few of the country dummies are significant, while the joint dummy in the partial model is not statistically significant. Thus, as with wages, there is no clear evidence that foreign ownership affects unions' bargaining power over employment.

Considering the composite effect from increases in $\mathbf{z}_{1}$ and $\mathbf{z}_{2}$, the estimation results are consistent with the first three derivatives in Eq. (10), i.e. $\partial L^{* /} / \partial \Phi_{1}<0, \partial L^{*} / \partial \Phi_{2}>0$ and $\partial w^{*} /$ $\partial \Phi_{1}>0$. The fourth derivative that could not be signed in (10), i.e. the effect on wages due to an increase in the trade union's bargaining power over employment, is positive: $\partial w^{*} / \partial \Phi_{2}>0$.

The results indicate that the point estimate of trade unions' bargaining power over wages is greater than the point estimate of their bargaining power over employment. However, the difference is not statistically significant, and thus, we cannot reject that the efficient bargaining model holds both for Swedish-owned forms and (since we find no significant overall effect of foreign ownership on bargaining strength) for foreign-owned firms.

\section{Discussion and conclusions}

In this paper, we used a sequential bargaining model between firms and trade unions to study the effects of foreign ownership on wages and employment. The hypothesis is that 
Table 2 Estimation results for the employment equation (GMM estimation)

\begin{tabular}{|c|c|c|c|c|}
\hline & Partial mod & & Full model & \\
\hline & Estimate & Standard error & Estimate & Standard error \\
\hline Wage & $-0.3592^{* * *}$ & 0.0731 & $-0.3009^{* * *}$ & 0.0724 \\
\hline Capital & $0.2956^{* * *}$ & 0.0136 & $0.2807^{* * *}$ & 0.0130 \\
\hline Producer price index & $0.2277^{* * *}$ & 0.0806 & $0.1800^{* * *}$ & 0.0797 \\
\hline Openness & $-0.1217^{* * *}$ & 0.0495 & $-0.1064^{* * *}$ & 0.0401 \\
\hline Union density & 0.8677 & 0.5560 & $0.7273^{*}$ & 0.3658 \\
\hline Foreign ownership & 0.1735 & 0.2542 & - & - \\
\hline Austria and Switzerland & & & 0.1444 & 0.1162 \\
\hline Belgium and Netherlands & & & 0.1797 & 0.0970 \\
\hline Denmark & & & 0.1307 & 0.1372 \\
\hline UK and Ireland & & & $-0.2233^{* * *}$ & 0.0859 \\
\hline Finland & & & -0.1049 & 0.0820 \\
\hline France & & & 0.0543 & 0.0987 \\
\hline Germany & & & 0.0130 & 0.0773 \\
\hline Italy & & & -0.2355 & 0.1939 \\
\hline Norway & & & -0.0741 & 0.1194 \\
\hline US and Canada & & & 0.0502 & 0.0708 \\
\hline Time & $2.16 \times 10^{-3}$ & $2.25 \times 10^{-3}$ & 0.0010 & 0.0022 \\
\hline Constant & -4.9627 & 4.4617 & $-0.6338^{* * *}$ & 0.0818 \\
\hline Mean $\Phi_{2}$ & $0.6036^{* * *}$ & $0.083^{a}$ & $0.6424^{* * *}$ & $0.0702^{\mathrm{a}}$ \\
\hline$R$-squared & 0.3216 & & 0.3331 & \\
\hline Durbin-Watson & 0.4385 & & 0.7626 & \\
\hline$F$ test & 7.5218 & & & \\
\hline
\end{tabular}

***0.1\% level; *5 \% level

aThe Delta method was used to calculate the standard errors

the bargaining power of the trade union may differ depending on the management and ownership of the firm. One advantage of the sequential bargaining approach is that the bargaining power of the trade unions and firms is allowed to differ between the wage-setting stage and the employment negotiations.

Openness turned out to have a significant effect in the employment-setting model but not in the wage-setting model. Union density has a positive sign in both the wage and the employment equation but is not significant in either equation. The results from the wage equation also indicate that increased unemployment will reduce the bargaining power for the trade union and drive wages down. Moreover, the results indicate that the trade union's bargaining power over wages is the same as (or at least not significantly different from) its bargaining power over employment. Manning (1987) argues that differences in bargaining power between different issues are a key driver of inefficiencies linked to unionisation, so the fact that we find no evidence of such differences is an interesting result in its own right.

However, the key topic of our study was the effect of foreign ownership on unions' bargaining strength. Our results indicate that foreign ownership has no statistically significant impact on unions' bargaining power over employment or wages. Thus, we cannot reject the hypothesis that both factors are unaffected by the ownership of the firm. Some previous studies have found higher wages in foreign-owned firms than in domestically owned firms; we find no such effect. 
Sweden previously had a number of regulations that limited FDI. The era of deregulation worried many because of concerns about impacts of foreign ownership-especially as regards the setting of wages (but also impacts on employment). Similar concerns have been raised in many other countries. The approach we applied in this study made it possible to test whether foreign ownership has in fact impacted on union bargaining power over wages and employment. Our study shows that foreign ownership in Sweden over the period in question had no significant impact on either of these variables, suggesting that the concerns about foreign ownership may have been unfounded.

\section{Endnotes}

${ }^{1}$ If $\Phi_{1}<1$ and $\Phi_{2}=0$, we have the right-to-manage model.

${ }^{2}$ If the production function is of a Cobb-Douglas type, it can be shown that the wagesetting rule is independent of the employment level and, hence, also independent of $\Phi_{2}$, bargaining power over employment (see e.g. Manning 1987).

${ }^{3}$ We have excluded trade union members living on unemployment benefits from the instrumental set since this variable may be endogenous for the labour equation.

\section{Appendix}

Table 3 Industries included in the data set

\begin{tabular}{|c|c|}
\hline $\mathrm{SIC}$ & Industries \\
\hline 154,155 and 158 & $\begin{array}{l}\text { Manufacture of } \\
\text { - Vegetable and animal oils and fats, } \\
\text { - Dairy products, and } \\
\text { - Other food products }\end{array}$ \\
\hline 211 & Manufacture of pulp, paper and paperboard \\
\hline 241 & Manufacture of basic chemicals \\
\hline 243,245 and 246 & $\begin{array}{l}\text { Manufacture of } \\
\text { - Paints, varnishes and similar coatings, printing ink and mastics, } \\
\text { - Soap and detergents, cleaning and polishing preparations, perfume and toilet } \\
\text { preparations, and } \\
\text { - Other chemical products }\end{array}$ \\
\hline 261 & Manufacture of glass and glass products \\
\hline 265,266 and 268 & $\begin{array}{l}\text { Manufacture of } \\
\text { - Cement, lime and plaster, } \\
\text { - Articles of concrete, plaster and cement, and } \\
\text { - Other non-metallic mineral products }\end{array}$ \\
\hline 272,273 and 274 & $\begin{array}{l}\text { Manufacture of } \\
\text { - Tubes, } \\
\text { - Other first processing of iron and steel, and } \\
\text { - Basic precious and non-ferrous metals }\end{array}$ \\
\hline 282 and 283 & $\begin{array}{l}\text { Manufacture of } \\
\text { - Tanks, reservoirs and containers of metals, central heating radiators and boilers, and } \\
\text { - Steam generators, except central heating hot water boilers }\end{array}$ \\
\hline 286, 291 and 295 & $\begin{array}{l}\text { Manufacture of } \\
\text { - Cutlery, tools and general hardware, } \\
\text { - Machinery for the production and use of mechanical power, except aircraft, vehicle } \\
\text { and cycle engines, and } \\
\text { - Other special purpose machinery }\end{array}$ \\
\hline 313 and 314 & $\begin{array}{l}\text { Manufacture of } \\
\text { - Insulated wire and cable, and } \\
\text { - Accumulators, primary cells and primary batteries }\end{array}$ \\
\hline
\end{tabular}


Table 4 Variables and their definitions

\begin{tabular}{|c|c|}
\hline Variable & Definition \\
\hline Reservation wage & Calculated from the lowest wage (in SEK) in the sample \\
\hline Employment & $\begin{array}{l}\text { The number of employed individuals in each firm in each year; employees } \\
\text { include both blue- and white-collar workers }\end{array}$ \\
\hline Openness & $\begin{array}{l}\text { The measure of industry openness; calculated as (total export + total import) / } \\
\text { total sales in each industry and year }\end{array}$ \\
\hline Union density & $\begin{array}{l}\text { Calculated for each trade union, the number of members (excluding supporting } \\
\text { members) divided by total employment in the industry (the link between } \\
\text { industry and trade union is determined using each trade union's definition of } \\
\text { their members according to their annual reports) }\end{array}$ \\
\hline Wage & The real wage, calculated as nominal wage divided by the consumer price index \\
\hline Capital & $\begin{array}{l}\text { The value of physical capital (machinery, buildings and inventories) divided by } \\
\text { the PPI }\end{array}$ \\
\hline PPI & Producer price index \\
\hline Unemployment level & $\begin{array}{l}\text { The average unemployment level in per cent for each trade union's membership, } \\
\text { as obtained from Swedish Public Employment Service statistics }\end{array}$ \\
\hline Foreign ownership & A dummy variable: 1 for foreign-owned, 0 for domestic-owned \\
\hline Austria and Switzerland & A dummy variable for owner's domicile: 1 for Austria or Switzerland, 0 for all others \\
\hline Belgium and Netherlands & $\begin{array}{l}\text { A dummy variable for owner's domicile: } 1 \text { for Belgium or The Netherlands, } \\
0 \text { for all others }\end{array}$ \\
\hline Denmark & A dummy variable for owner's domicile: 1 for Denmark, 0 for all others \\
\hline UK and Ireland & A dummy variable for owner's domicile: 1 for UK or Ireland, 0 for all others \\
\hline Finland & A dummy variable for owner's domicile: 1 for Finland, 0 for all others \\
\hline France & A dummy variable for owner's domicile: 1 for France, 0 for all others \\
\hline Germany & A dummy variable for owner's domicile: 1 for Germany, 0 for all others \\
\hline Italy & A dummy variable for owner's domicile: 1 for Italy, 0 for all others \\
\hline Norway & A dummy variable for owner's domicile: 1 for Norway, 0 for all others \\
\hline US and Canada & A dummy variable for owner's domicile: 1 for the USA or Canada, 0 for all others \\
\hline Time & A trend variable \\
\hline
\end{tabular}

Table 5 Sample statistics; standard deviations in brackets

\begin{tabular}{llllllll}
\hline Employment & $\begin{array}{l}\text { Real } \\
\text { wage }\end{array}$ & $\begin{array}{l}\text { Real } \\
\text { capital }\end{array}$ & $\begin{array}{l}\text { Trade union } \\
\text { density }\end{array}$ & Openness & $\begin{array}{l}\text { Unemployment } \\
\text { level }\end{array}$ & $\begin{array}{l}\text { Producer price } \\
\text { index (PPI) }\end{array}$ & Obs. \\
\hline $315(394)$ & $272(147)$ & $95117(199378)$ & $0.8151(0.0690)$ & $1.0474(0.5952)$ & $0.0590(0.0303)$ & $1.983(0.502)$ & 4379 \\
\hline
\end{tabular}


Table 6 Share of owner's domiciles within the data set (\%)

\begin{tabular}{|c|c|c|c|c|c|c|c|c|c|c|c|}
\hline Year & Sweden (\%) & Austria/Switzerland (\%) & Belgium/Netherlands (\%) & Denmark (\%) & UK/Ireland (\%) & Finland (\%) & France (\%) & Germany (\%) & Italy (\%) & Norway (\%) & US/Canada (\%) \\
\hline 1980 & 60.0 & 2.9 & 1.4 & 0.7 & 5.7 & 1.4 & 2.1 & 4.3 & 0.0 & 1.4 & 5.7 \\
\hline 1981 & 59.6 & 2.8 & 2.1 & 0.7 & 5.0 & 1.4 & 2.8 & 4.3 & 0.0 & 1.4 & 6.4 \\
\hline 1982 & 59.0 & 3.5 & 2.8 & 0.7 & 4.9 & 1.4 & 2.8 & 4.2 & 0.0 & 1.4 & 6.3 \\
\hline 1983 & 56.6 & 3.1 & 2.5 & 0.6 & 5.0 & 1.3 & 2.5 & 5.7 & 0.6 & 0.6 & 6.9 \\
\hline 1984 & 59.0 & 3.7 & 2.5 & 0.6 & 4.3 & 1.2 & 2.5 & 4.3 & 0.6 & 0.6 & 6.8 \\
\hline 1985 & 58.6 & 4.0 & 2.3 & 0.6 & 4.0 & 1.1 & 2.3 & 4.6 & 0.6 & 0.6 & 6.9 \\
\hline 1986 & 55.8 & 4.4 & 3.3 & 1.1 & 4.4 & 2.8 & 2.8 & 5.0 & 0.6 & 0.6 & 6.1 \\
\hline 1987 & 54.7 & 4.4 & 2.8 & 1.1 & 3.9 & 3.3 & 3.3 & 5.5 & 0.6 & 0.6 & 6.6 \\
\hline 1988 & 53.0 & 5.4 & 3.2 & 1.1 & 3.2 & 3.8 & 3.8 & 5.4 & 0.5 & 0.5 & 6.5 \\
\hline 1989 & 50.5 & 6.8 & 3.6 & 1.0 & 3.6 & 5.7 & 3.6 & 5.2 & 0.5 & 0.5 & 5.7 \\
\hline 1990 & 46.3 & 8.4 & 3.4 & 1.0 & 3.0 & 8.4 & 3.9 & 5.4 & 0.5 & 2.0 & 5.4 \\
\hline 1991 & 44.7 & 7.6 & 4.1 & 1.5 & 3.6 & 8.6 & 4.6 & 5.6 & 0.5 & 2.5 & 5.6 \\
\hline 1992 & 43.2 & 7.5 & 3.5 & 1.5 & 3.0 & 9.0 & 4.5 & 8.0 & 0.5 & 3.0 & 5.5 \\
\hline 1993 & 41.6 & 6.8 & 3.7 & 1.6 & 4.2 & 10.5 & 4.2 & 7.9 & 0.5 & 4.2 & 5.8 \\
\hline 1994 & 34.0 & 5.8 & 8.0 & 2.7 & 8.5 & 11.2 & 4.3 & 8.0 & 0.5 & 4.8 & 6.4 \\
\hline 1995 & 31.5 & 5.7 & 8.4 & 1.7 & 7.3 & 10.7 & 3.4 & 8.4 & 0.6 & 4.5 & 6.2 \\
\hline 1996 & 31.1 & 6.2 & 8.9 & 1.7 & 7.8 & 10.6 & 3.3 & 7.8 & 0.6 & 4.4 & 6.7 \\
\hline 1997 & 30.0 & 6.2 & 8.9 & 1.7 & 8.3 & 11.1 & 4.4 & 8.9 & 0.6 & 3.9 & 7.3 \\
\hline 1998 & 29.0 & 6.9 & 8.5 & 1.7 & 9.1 & 11.4 & 4.0 & 9.1 & 0.6 & 4.5 & 6.9 \\
\hline 1999 & 28.6 & 6.0 & 8.3 & 1.2 & 10.1 & 13.7 & 4.2 & 8.3 & 1.2 & 4.2 & 7.1 \\
\hline 2000 & 27.4 & 6.1 & 9.1 & 1.2 & 9.8 & 12.8 & 4.3 & 7.9 & 1.2 & 4.3 & 7.9 \\
\hline 2001 & 26.8 & 5.9 & 9.8 & 1.3 & 10.5 & 11.8 & 4.6 & 7.2 & 1.3 & 4.6 & 9.2 \\
\hline
\end{tabular}


Table 6 Share of owner's domiciles within the data set (\%) (Continued)

\begin{tabular}{|c|c|c|c|c|c|c|c|c|c|c|c|}
\hline 2002 & 26.9 & 5.5 & 10.4 & 1.4 & 9.0 & 13.1 & 4.8 & 7.6 & 1.4 & 4.1 & 9.7 \\
\hline 2003 & 25.7 & 5.7 & 10.7 & 1.4 & 8.6 & 13.6 & 5.0 & 7.1 & 1.4 & 4.3 & 10.0 \\
\hline 2004 & 25.6 & 6.1 & 12.1 & 1.5 & 7.5 & 13.5 & 4.5 & 7.5 & 1.5 & 4.5 & 10.5 \\
\hline 2005 & 26.0 & 7.1 & 11.8 & 1.6 & 6.3 & 11.8 & 5.5 & 7.9 & 1.6 & 3.9 & 11.0 \\
\hline
\end{tabular}




\section{Competing interests}

The IZA Journal of European Labor Studies is committed to the IZA Guiding Principles of Research Integrity. The authors declare that they have observed these principles.

\section{Acknowledgements}

Financial support from the Jan Wallander and Tom Hedelius Foundation and Formas is gratefully acknowledged. Magnus Wikström and Karl-Gustaf Löfgren at the Department of Economics, Umeå University, and an anonymous reviewer and the editor provided constructive comments on earlier versions of this paper. Sandie Fitchat provided valuable help with language editing. The usual disclaimers apply.

Responsible editor: Alan Barret

\section{Author details}

${ }^{1}$ Department of Economics, Umeå University, SE-901 87 Umeå, Sweden. ²Department of Food and Resource Economics, University of Copenhagen, Rolighedsvej 25, DK-1958 Frederiksberg, C, Denmark. ${ }^{3}$ Department of Business Administration, Technology and Social Sciences, Luleå University of Technology, SE 97187 Luleå, Sweden. ${ }^{4}$ Department of Business, Economics and Law, Mid Sweden University, SE-851 70 Sundsvall, Sweden.

Received: 17 November 2015 Accepted: 22 February 2016

Published online: 29 April 2016

\section{References}

Aitken B, Harrison A, Lipsey RE (1996) Wages and foreign ownership: a comparative study of Mexico, Venezuela, and the United States. Journal of International Economics 40:345-371

Almeida R (2007) The labor market effects of foreign owned firms. Journal of International Economics 72:75-96

Alogoskoufis G, Manning A (1991) Tests of alternative wage employment bargaining models with an application to the UK aggregate labour market. European Economic Review 35:23-37

Arellano M (ed) (2003) Panel data econometrics. Oxford University Press, Oxford

Bandick R, Karpaty P (2011) Employment effects of foreign acquisition. International Review of Economics and Finance 20:211-224

Bughin J, Vannini S (1995) Strategic direct investment under unionized oligopoly. International Journal of Industrial Organization 13:127-145

Conyon MJ, Girma S, Thompson S, Wright PW (2002) The productivity and wage effects of foreign acquisition in the United Kingdom. Journal of Industrial Economics 50:85-102

Cowling K, Sugden R (1987) Transnational monopoly capitalism. Wheatsheaf, Brighton

Doiron DJ (1992) Bargaining power and wage-employment contracts in a unionized industry. International Economic Review 33:583-606

Dumont M, Rayp G, Willemé P (2012) The bargaining position of low-skilled and high-skilled workers in a globalising world. Labour Economics 19:312-319

Dunlop JT (1944) Wage determination under trade unions. Macmillan, New York

Feliciano Z, Lipsey RE (1999) Foreign ownership and wages in the United States, 1987-1992. In: National Bureau of Economic Research Working Paper Series No. 6923

Girma S, Greenaway D, Wakelin K (2001) Who benefits from foreign direct investment in the UK? Scottish Journal of Political Economy 48:119-133

Griffith R, Simpson H (2003) Characteristics of foreign-owned firms in British manufacturing. In: National Bureau of Economic Research Working Paper Series No. 9573

Hatzius J (2000) Foreign direct investment and factor demand elasticities. European Economic Review 44:117-143

Hausman JA (1983) Specification and estimation of simultaneous equation models. In: Griliches Z, Intriligator MD (eds) Handbook of econometrics. Elsevier, Amsterdam

Huizinga H (1990) Unions, taxes and the structure of multinational enterprises. Economics Letters 34:73-75

Huttunen K (2007) The effect of foreign acquisition on employment and wages: evidence from Finnish establishments. Review of Economics and Statistics 89:497-509

Leamer EE (1987) Measures of openness. UCLA Working Paper 447

Lipsey RE (1994) Foreign-owned firms and US wages. In: National Bureau of Economic Research Working Paper Series No. 4927

Manning A (1987) An integration of trade union models in a sequential bargaining framework. Economic Journal 97 : $121-139$

Martins PS (2004) Do foreign firms really pay higher wages? Evidence from different estimators. In: IZA Discussion Paper No. 1388

Martins PS, Esteves LA (2008) Foreign ownership, employment and wages in Brazil: evidence from acquisitions, divestments and job movers. In: IZA Discussion Paper No. 3542

McDonald IM, Solow RM (1981) Wage bargaining and employment. The American Economic Review 71:896-908

Modén K-M (1998) Foreign acquisition of Swedish companies-effects on R\&D and productivity. ISA Studies on Foreign Direct Investment 1998/2, Invest in Sweden Agency

Navaretti GB, Checchi D, Turrini A (2003) Adjusting labor demand: multinational versus national firms: a cross-European analysis. Journal of the European Economic Association 1:708-719

Naylor R, Santoni M (2003) Foreign direct investment and wage bargaining. Journal of International Trade and Economic Development 12:1-18

Radulescu R, Robson M (2008) Trade unions, wage bargaining coordination, and foreign direct investment. Labour 22: $661-678$

Ramsay H (1995) Euro-unionism and the great auction: an assessment of the prospects for the European labour movement post-Maastricht. Labour and Industry 6:13-44 
Vannetelbosch VJ (1996) Testing between alternative wage-employment bargaining models using Belgian aggregate data. Labour Economics 3:43-64

Zhao L (1995) Cross-hauling direct foreign investment and unionized oligopoly. European Economic Review 39:1237-1253

Zhao L (1998) The impact of foreign direct investment on wages and employment. Oxford Economic Papers 50:284-301

\section{Submit your manuscript to a SpringerOpen ${ }^{\circ}$} journal and benefit from:

- Convenient online submission

- Rigorous peer review

- Immediate publication on acceptance

- Open access: articles freely available online

- High visibility within the field

- Retaining the copyright to your article

Submit your next manuscript at $>$ springeropen.com 